\title{
DiSAGGREGATED SOUTH AFRICAN HOUSEHOLD NET WEALTH: A MIXED METHODS APPROACH
}

\author{
Debbie Scheepers* \\ University of South Africa
}

Received: April 2016

\author{
Bernadene de Clercq ${ }^{*}$ \\ University of South Africa
}

Accepted: July 2016

\begin{abstract}
This article addresses the paucity of disaggregated household net wealth data in South Africa. A mixed methods approach was followed to develop and conduct a country-specific household net wealth measurement survey. A disaggregated household typology of assets and liabilities, based on international net wealth surveys, was developed. Focus group research was employed in the qualitative strand to finalise the survey. In the quantitative strand, disaggregated micro-level data estimates from 2606 households were collected and the article presents the cursory findings. A comparison is drawn between the survey's main asset and liability estimates with data estimates presented in the South African Reserve Bank's household balance sheet. These estimates were constructed from macrolevel data estimates and lack information on the disaggregated composition of household net wealth. Furthermore, the conceptual linkages and differences between the micro and macro data estimates are described. The manner in which differences in the concepts, construction methods and potential survey errors contributed to differences between the two sets of data estimates is also indicated. The aim of the research was to contribute to the field of household finances from the perspective of a developing country. Therefore, the process followed to construct and validate the survey instrument and data estimates could assist other developing countries to develop their own surveys. Disaggregated net wealth data estimates could assist policy-makers with the overview and management of a country's household net wealth.
\end{abstract}

\section{Keywords}

Household net wealth measurement, household assets, household liabilities, household balance sheet, mixed methods research, focus group research, disaggregated household data estimates

*Prof D Scheepers is a professor in the Department of Financial Accounting, University of South Africa, South Africa [scheed@unisa.ac.za].

\#Prof B de Clercq is an associate professor in the Department of Taxation, University of South Africa, South Africa. 


\section{INTRODUCTION}

The aim of a country's macroeconomic policy is to improve the lives of citizens and, by implication, households through the stabilisation of the economy and the amelioration of negative economic impacts (Fourie \& Burger, 2011). A country's macroeconomic policy is aimed to enhance economic growth and development, increase employment, and stabilise inflation, thereby assisting in the reduction of poverty (Fourie \& Burger, 2011; NPC, 2013; 0ECD, 2013). The household sector is one of the main decision-making units in any economy and consists of all residential households in a country. Households (the unit of analysis in this article) own assets, they acquire liabilities, and engage with other economic units (government, financial institutions and legal entities) in their own right. They are the primary consuming unit in an economy and play a vital role in any country's economic well-being (Case, Fair \& Oster, 2009; Fourie \& Burger, 2011). While a myriad of household definitions exists in the literature, it is one of the objectives of this study to define a household in the manner that encapsulates the multiple living arrangements of South African citizens.

The financial crisis of 2008 indicated that many households in developing and developed countries had accumulated unsustainable debt levels due to lenient debt access and overzealous house prices. To determine the effect of possible economic imbalances and associated risks, a country needs reliable information on the level, composition and distribution of household financial net wealth across individual households with different characteristics. Composition refers to the dissection or disaggregation of the level of net wealth in terms of types of assets and liabilities owned/owed, while distribution refers to the spread of net wealth across the household population associated with certain characteristics (OECD, 2013:28).

Household net wealth or net worth is generally defined in studies as the difference between the measured values of the accumulated assets of a household after deducting the measured values of its accumulated liabilities on the pre-determined measurement date. It is the view of the Organisation for Economic Co-operation and Development (OECD) (2013:7-11) that reliable data on household asset and liability composition and distribution could assist policy-makers to understand how financial shocks affect the structure of household net wealth with specific reference to 'indebtedness'. Furthermore, it could ensure that policy-makers are in a position to anticipate shocks and react with timeous interventions. The potential costs to the fiscus as well as which households and to what extent they will be impacted by proposed tax amendments can be identified. Monitoring the success of tax incentives in improving savings rates is possible by gauging the uptake of the recently introduced tax-free savings products over time. With the support of compositional and distributional net wealth household data, evidence-based policy interventions can thus be contemplated and implemented.

Countries use either the indirect or the direct approach to measure household sector net wealth. The indirect approach uses secondary data to construct net wealth estimates from either counterpart data estimates or residual estimates (Aron, Muelbauer \& Prinsloo, 2007). This approach is used to construct the System of National Accounts (SNA), which is the accepted international statistical framework for the preparation of national accounts for all economic units in a country (United Nations, European Commission, Organisation for Economic Cooperation and Development, International Monetary Fund \& World Bank Group, 2009:iii). In South Africa, the South African Reserve Bank (SARB) currently presents the assets and liabilities of the household sector as macroeconomic data estimates in its household balance sheet (SARB, 2014). The SNA constructs the household balance sheet from counterpart data estimates (estimates provided by financial institutions) and residual estimates (estimates that are residually 
allocated to data poor sectors) (Aron et al., 2007). However, these estimates lack detail on the composition and associated measurement of the different asset and liability classes (UN et al., 2009). Apart from the liability section, which comprises mortgages and other debt, the SARB household balance sheet reflects two broad categories of assets: non-financial and financial assets (SARB, 2014:S-134). The former comprises residential buildings and other non-financial assets, whereas the latter comprises assets with monetary institutions, interest in pension funds and long-term insurers and other financial assets (SARB, 2014:S-134).

Conversely, the direct approach to household sector net wealth measurement is making use of survey data (Aron et al., 2007). When direct or survey data is used, it is possible to obtain detailed composition and measurement information of the different asset and liability classes that households invest in or owe (UN et al., 2009:462). The disaggregated information, in turn, assists in determining the distribution of net wealth across different types of households, and assists with feeding disaggregated information into the SNA.

The practice of measuring household net wealth by means of the direct approach via a household survey is a global phenomenon (Black, 2011; Bloxham \& Betts, 2009; Bover, 2008; Carasso \& McKerman, 2007; Daffin, 2009; عCB/HFCN, 2009; Jantti, Sierminska \& Smeeding, 2008; Kennickel, 2009; 0ECD, 2013; Shorrocks, Davies \& Lluberas, 2012). The number of countries that measure household net wealth directly and indirectly is increasing. South Africa, as a developing country, has also contributed to this discourse, but up until the time of this study, the indirect approach applied by the SARB was the only household sector data source available that provided information in its household balance sheet on household net wealth at national level (Aron et al., 2006 \& 2007; Kuhn, 2010). In this article, the terms 'financial position' and 'balance sheet' are used interchangeably because of their similar meaning. The paucity of disaggregated micro-level data estimates provided the purpose of the study, namely, to systematically develop a net wealth measurement instrument, specifically relevant to South Africa as a developing country, which could be used to collect disaggregated household data estimates. The survey that was developed in this study is currently conducted annually in South Africa, and five data collection phases have been conducted to date.

South African studies applying the direct approach have followed this study (Brown, Daniels, De Villiers, Leibbrandt \& Woolard, 2012; Woolard, Leibbrandt \& Daniels, 2014). It was, however, only after the data was collected in this study that the South African Labour and Development Research Unit (SALDRU), which conducts the National Income and Dynamics Study (NIDS), included a section on individual wealth measurement in the second data collection phase of its study (Brown et al., 2012; Woolard et al., 2014).

This article presents the development process of the instrument used to obtain disaggregated household net wealth data, as well as the cursory data collected in the first collection phase of the nationally representative survey. The validation of the data estimates is presented by conceptualising micro and macro linkages and exploring possible reasons for any differences. The article further highlights the use of a mixed methods design in household data collection. It should be noted that the researchers could not find another study that applied this approach to collect net wealth household data estimates. 


\section{RESEARCH DESIGN AND METHODOLOGY}

As mentioned in the introduction, direct household net wealth measurement in most countries is done quantitatively through survey research. Contrary to international practice, the researchers decided to incorporate a mixed methods design in this study to develop an instrument that is used to collect disaggregated household net wealth data. According to Onwuegbuzie, Bustamante and Nelson (2010) and Onwuegbuzie and Leech (2006), when researchers apply a mixed methods design to better understand both the breadth and depth of a concept, they apply a pragmatic paradigm. In this study, the qualitative strand was conducted before the quantitative strand, which implies that a mixed methods exploratory sequential design was followed (Creswell \& Plano Clark, 2011; Edmeades, Nyblade, Malhotra, MacQuarrie, Parasuraman \& Walia, 2010; Johnson \& Onwuegbuzie, 2004). The study was therefore conducted in several stages across the qualitative and quantitative strands as illustrated in FIGURE 1:

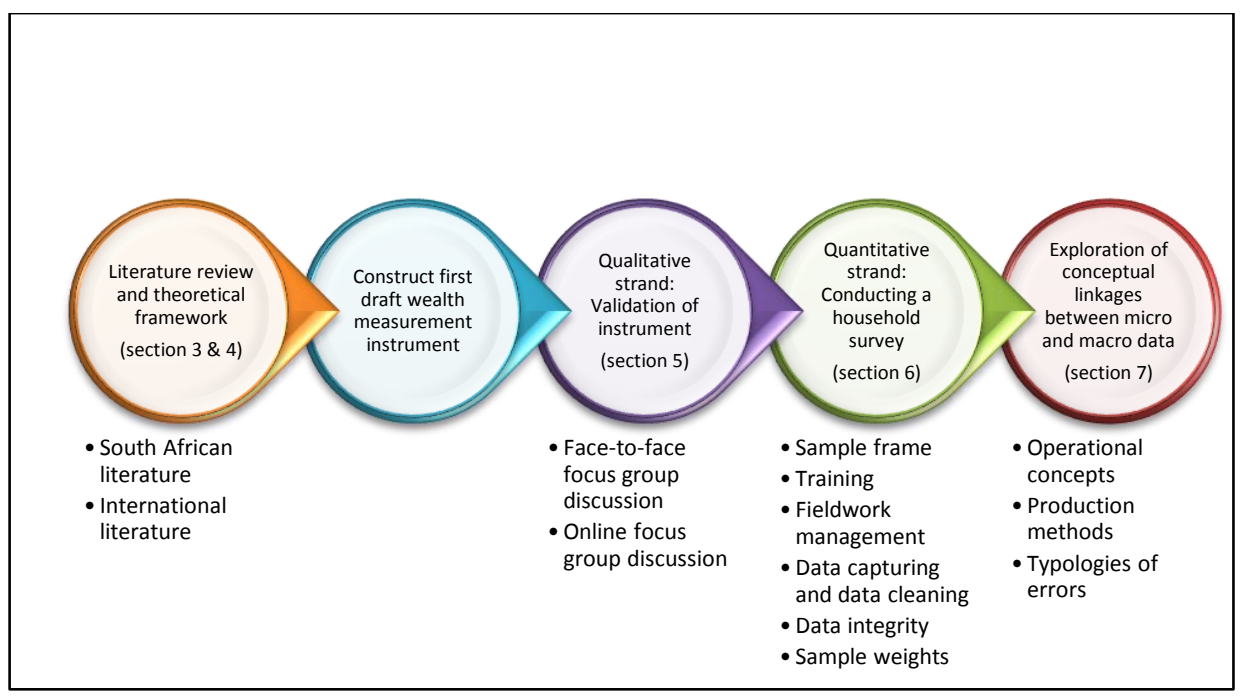

\section{FIGURE 1: Illustration of the research design and the stages discussed in the article}

\section{Source: Authors'compilation}

The study commenced with a national literature review to establish the existence and depth of household net wealth studies in South Africa. The paucity of such data at the time necessitated the construction of a dedicated net wealth measurement instrument. An international literature review on net wealth measurement instruments was then conducted to determine a typology of assets and liabilities. This was used to compile a draft instrument for household net wealth measurement.

Before the commencement of the qualitative strand, ethical clearance to conduct the study was obtained from the University of South Africa's (UNISA) Research Ethics Review Committee. The study implemented focus group research in the qualitative research strand to obtain the in-depth knowledge of specialists in household finances regarding the composition and measurement abilities of the draft instrument. The participants in the study were informed that their participation was voluntary; however, anonymity could not be offered for the face-to-face focus group participants, although identifying information was minimised to maintain confidentiality. The aim of the qualitative strand was to ensure that the instrument was both comprehensive and 
trustworthy. The latter was established by benchmarking the disaggregated asset and liability typology with national (NIDS) and international studies (OECD). Based on the input received from the focus group participants, the construction of an improved and robust instrument was accomplished and the instrument was used to collect micro-level household data estimates in the quantitative strand.

The quantitative strand of the study describes the method, sample design and training during the fieldwork phase. During the data collection process, anonymity of participating households was retained and households were informed that they could withdraw from the interview process at any time.

Similar to what is prescribed by the $0 E C D$ (2013) to validate household net wealth data estimates, conceptual linkages and differences were established between the household net wealth data estimates obtained from the measurement instrument (micro-level data) and the household balance sheet data prepared from national accounts (macro-level data). The cursory data estimates from the first data collection phase are presented and compared with the SARB household balance sheet data estimates. Subsequently, the reasons for the differences are explored and shortcomings in the quality of the data are aired.

\section{OVERVIEW OF NATIONAL AND INTERNATIONAL NET WEALTH MEASUREMENT INSTRUMENTS}

It was clear from the national literature review conducted (Scheepers, 2014) that the focus of existing South African household studies was mostly on the distribution and measurement of household income and expenditure rather than on the determination of household net wealth (Bhorat, Van der Westhuizen \& Cassim, 2009; Finmark Trust, 2010; Masemola, Van Aardt \& Coetzee, 2011; SAARF, 2010; SSA, 2010; SAA, 2011 la-d; Van Aardt \& Moshoeu, 2009). The profound contribution of these studies is not denied; however, these studies focused on usage rather than measurement, and presented limited asset and liability disaggregation. The Finmark trust (2010) study identified financial assets and liability classes specifically in use in South African financial markets such as 'Mzansi' accounts (low-cost bank accounts), burial society policies, garage and petrol card accounts, 'stokvels' (informal savings clubs) and informal borrowing such as 'mashonisas' (loan sharks). However, the study only provided usage data on the mentioned financial asset classes.

Due to the limited contribution of national household studies towards identifying and measuring disaggregated asset and liability classes, the literature review was extended to include prominent international net wealth measurement surveys. The review included institutions in developed countries that are recognised leaders in net wealth measurement, namely, the United States of America, Australia, New Zealand, Canada, Great Britain and European countries. The following comprehensive surveys were used to form the basis for the South African net wealth measurement instrument:

- United States of America - The Survey of Consumer Finances (Kennickell, 2000; Campbell, 2006; Bricker, Bucks, Kennickell, Mach \& Moore, 2011);

- Australia - The Household Income and Labour Dynamics survey (HILDA) (Heady \& Wooden, 2005; Creedy \& Tan, 2007; Bloxham \& Betts, 2009;) and the Survey of Income and Housing (SIH) (ABS, 2011); 
- New Zealand - The Survey of Families, Income and Employment (SOFIE) (Le, Gibson \& Stillman, 2010);

- Canada - The Survey of Household Spending (SHS) (SC, 2010);

- Great Britain - Wealth and Assets Survey (WAS) (Black, 2011);

- The European area - Household Finance and Consumption Survey (HFCS). Since 2008, the European Central Bank $(\varepsilon C B)$ has conducted variations of this survey in 15 Euro area countries. The literature review therefore incorporated the core output variables of the HFCS (Sanchez-Munoz \& Tzamourani, 2008).

The international literature review also included developing countries that already measured household net wealth with the aid of survey data. The measurement instruments of China, India, Indonesia, Moldova and Turkey (IHSN, 2001 \& 2006; Subramanian \& Jayaraj, 2006; Li \& Zhao, 2007; RAND Family Life Surveys, 2007) were perused for additional asset and liability classes.

From the international literature review, it was evident that the Wealth and Asset survey (WAS) of Great Britain had the most asset and liability classes. The asset and liability classes in the WAS and other surveys were considered for inclusion in the South African net wealth measurement instrument. The prerequisites for inclusion were the ability to disaggregate the current SARB household balance sheet categories, and the familiarity of the South African household sector with utilising the disaggregated asset and liability classes. According to Malpezzi (2000:305) the questions used in other surveys could be an indication of the type of questions to ask; however, every survey should be country-specific to ensure concise, accurate and relevant data based on the experience and use of various financial instruments, financing options, and products that are available and in use in a specific country. The literature review assisted with a typology of asset and liability classes to disaggregate South African household net wealth. In the following section, the theoretical framework underpinning the study is presented.

\section{THEORETICAL FRAMEWORK FOR CLASSIFICATION AND MEASUREMENT}

Utilising the prescriptive nature of accounting principles, the accounting Conceptual Framework (SAICA, 2014a) was adopted to assist in the classification and measurement of the disaggregated asset and liability classes. However, to enable the use of a recognised business entity framework for households, the study had to adopt three underlying accounting postulates. The first is to view the household as an entity (Samphantharak \& Townsend, 2008), which is based on the Proprietary Theory of Husband (1954). This theory acknowledges that the household is an institution in its own right and that net wealth (or equity) is determined for the owners of the entity (household) by accounting for the owned assets, and deducting the liabilities that the household members owe. Secondly, the measurement of net wealth occurs at a specific moment in time, and thirdly, only measureable monetary assets and liabilities are included in net wealth measurement (RiahiBelkaoui, 2004).

The accounting Conceptual Framework (SAICA, 2014a) defines the elements that represent net wealth, namely, assets and liabilities, and prescribes the elements' measurement criteria. The framework's definition of an asset (SAICA, 2014a:A33 par. 4.4(a)) as 'a resource under the control of the entity, having an expected future economic benefit, and originating from past events' was applied to recognise the household asset classes. The identified asset classes constituted five main asset categories: non-current assets, other non-financial assets, retirement funding assets, financial assets and current assets (SAICA, 2014b). The accounting Conceptual Framework 
definition of a liability (SAICA, 2014a:A33 par. 4.4(b)) as 'a present obligation that arose from past events and on settlement, would result in an outflow of economic resources' was applied to recognise the household liability classes. The identified liability classes were categorised as noncurrent liabilities (mortgages), financial liabilities, and current liabilities (SAICA, 2014b). Classifying disaggregated asset and liabilities into main categories, similarly to how macro-level data estimates are classified, enables comparison of micro-level data estimates with macrolevel data estimates.

Measurement, alternatively, is the process of determining the monetary value of assets and liabilities (SAICA, 2014a:A42 par. 4.54). According to Barth (2008:1165), and Deegan (2010:226), there is an increasing propensity to adopt 'fair value' as the basis for the measurement of assets and 'present value' as the basis for the measurement of liabilities, and to move away from historical cost. In this study's survey, households were requested to provide a value or give their best estimate of the value (from a range of values) of each asset or liability item. The value of an asset was defined as the expected amount the household would receive by selling the asset on the measurement date. In the case of a liability, households were to report the amount or provide their best estimate (from a range of values) of the obligation owed at the measurement date. It is the view of the researchers that the classification and measurement principles embodied in the accounting Conceptual Framework, and implemented in the measurement instrument, assisted the participating households to recognise assets and liabilities owned/owed, and aided in their respective measurement.

\section{QUALITATIVE STRAND CONDUCTED TO VALIDATE THE MEASUREMENT INSTRUMENT}

In this strand, the trustworthiness and authenticity of the measurement instrument were validated with focus group research. The strand introduced a qualitative data collection methodology to improve the quantitative data collection associated with large-scale representative household surveys. The views and opinions of national and international household finance specialists were used to address three research sub-questions that arose during the development of the measurement instrument, namely: (i) Are all possible household asset and liability classes included and measurable? (ii) Who constituted a 'household' for purposes of the study? and (iii) Who would be a suitable interviewee? This was accomplished through a face-toface focus group discussion to obtain the views of national household specialists, and an online focus group discussion to obtain the views of international specialists in household net wealth measurement who could only be reached online. Although international specialists might not be familiar with country-specific assets and liabilities, their expert knowledge in conducting largescale household surveys for developing and developed countries was required.

The Bureau of Market Research (BMR) at UNISA provided a list of national and international household finance specialists from which two purposive samples of participants were selected based on their industry representation. The international specialists in household surveys were identified based on their publication record, and were included in the online focus group together with specialists that could not attend the face-to-face focus group session, but who were willing to comment online on the three research sub-questions. The composition and contribution of the two focus group discussions is subsequently presented. 


\subsection{Face-to-face focus group discussion}

Ten specialists and nine academics attended the face-to-face focus group discussion (Scheepers, 2014). Three specialists were from the banking sector, five specialists from the insurance sector, one from government, and one from a research institution. The high number of specialists was necessary to ensure the representation of most of the related industries and stakeholders. The academics were researchers in the household net wealth measurement project, who attended the discussions as stakeholders.

A semi-structured interview was used to guide the conversation during the face-to-face focus group discussion. From the feedback collected, themes and sub-themes were developed to address the research sub-questions. A summary of the results from the face-to-face focus group discussions concerning the research sub-questions is presented in TABLE 1 .

\section{TABLE 1: Summary of the research sub-questions and results from the face-to-face focus group discussion}

Are all possible household assets and liabilities included and measureable?

- The face-to-face focus group participants contributed alternative measures for property, vehicles and financing. The usefulness of these measures depended on a household's ability to answer a range of questions concerning interest rates, monthly payments, terms, and the number of outstanding payments.

- The participants mentioned that households could experience trouble in valuing insurance and retirement assets, and suggested caution be applied when interpreting responses. They identified funeral policies, special needs policies, and education policies to disaggregate the insurance category.

- The participants identified the following possible household current liabilities and bills: school fees, medical bills, alimony, municipal bills, television bills and cell phone airtime. The participants viewed cell phone handsets as financial liabilities.

- Lastly, the participants volunteered information on the most important demographics to include when analysing distribution. They identified age, income, employment status, education, gender, ethnicity, and province as important distribution variables.

Who constituted a 'household' for purposes of the study and who would be a suitable 'interviewee'?

- The participants could not agree on an interviewee or a final household definition that encapsulated the multiple living arrangements of South Africans. The decision was taken to pose the question to international specialists via the online focus group discussion to suggest a household definition and to assist with the identification of the most suitable interviewee.

Source: Scheepers (2014)

The improvements suggested by the face-to-face focus group participants were incorporated in the draft instrument and the improved instrument was circulated to the online focus group participants. 


\subsection{Online focus group discussion}

In total, 65 purposively selected participants (discussed in section 5 ) were invited to respond via email, and 18 responses were received. Four international specialists from the $\varepsilon C B$, the London School of Economics, and the universities of Nuffield and Bristol provided feedback, as well as three national participants from the banking industry, three from the insurance industry, and eight participants from the world of academia (Scheepers, 2014).

The responses, particularly the views of the international specialists, provided valuable insight, which led to obtaining permission to incorporate some of the core output variables from the HFCS survey ( $E C B / H F C N, 2009: 7)$ to assist in defining a 'household' and the 'interviewee' for purposes of the study as follows:

\footnotetext{
A household is an economic unit consisting of a person living alone or a group of people who live together in the same private dwelling and share expenditures, including the joint provision of the essentials of living. Employees of residents (i.e. live-in domestic servants, au pairs, etc.) and roommates without other family or partnership attachments to household members (e.g. resident boarders, lodgers, tenants, visitors, etc.) are considered as separate households.

Subject to the further and specific conditions shown below, the following persons must, if they share household expenses, be regarded as household members:

- persons usually resident, but temporarily absent from the dwelling (for reasons of holiday, travel, work, education or similar);

- children in the household being educated away from home;

- persons absent for long periods, but having household ties: persons working away from home; and

- persons temporarily absent but having household ties: persons in a hospital, nursing home, boarding school or other institution.

The interviewee is the 'financially knowledgeable person' (FKP). The FKP is defined as the person in the household who is the most knowledgeable about financial matters regarding both the household as a whole and its individual members.
}

Acting on the advice of the international participants, a screening section was provided in the accompanying survey manual, which was used to train the fieldworkers. The section identified the FKP and established the following measurement decision rules: the respondent was asked to supply a value and if he/she was unable to provide a value, a range of values to choose from was provided. The international participants suggested the inclusion of a 'nil' value and a 'don't know' or 'refuse to answer' option to cover responses where the respondent felt that he/she truly could not provide an estimate. One of the participants suggested the inclusion of 'other hire purchases' to encompass the purchase of collectibles and valuables by way of a finance agreement. The participants also provided valuable input, which improved the cover letter.

\subsection{Resulting focus groups' asset/liability typology and its validation}

TABLE 2 presents the typology of South African household assets and liabilities, which resulted from the literature review and the two focus group sessions. Incorporating the critique from the participants of both focus groups not only increased the content validity, but also ensured a comprehensive and robust net wealth measurement instrument. The main asset and liability categories classified according to the accounting Conceptual Framework (SAICA, 2014b) are indicated in bold. 


\section{TABLE 2: Contribution towards a typology of South African household assets and liabilities}

\begin{tabular}{|c|c|c|c|}
\hline $\begin{array}{c}\text { Asset and liability } \\
\text { classes identified from } \\
\text { the national literature } \\
\text { review }\end{array}$ & $\begin{array}{l}\text { Asset and liability } \\
\text { classes identified from } \\
\text { the international } \\
\text { literature review }\end{array}$ & $\begin{array}{l}\text { Asset and liability } \\
\text { classes identified via } \\
\text { the focus groups } \\
\text { discussions }\end{array}$ & $\begin{array}{l}\text { Asset and liability } \\
\text { classes included to } \\
\text { measure South African } \\
\text { household net wealth }\end{array}$ \\
\hline \multicolumn{4}{|c|}{ ASSETS } \\
\hline & & & Non-current assets \\
\hline & \multicolumn{2}{|l|}{ Main residence } & Main residence \\
\hline & \multicolumn{2}{|l|}{ Other property } & Other property \\
\hline & & & $\begin{array}{l}\text { Other non-financial } \\
\text { assets }\end{array}$ \\
\hline & \multicolumn{2}{|l|}{ Vehicles } & $\begin{array}{l}\text { Vehicles (including } \\
\text { boats and planes) }\end{array}$ \\
\hline & \multicolumn{2}{|l|}{$\begin{array}{l}\text { Contents (main and } \\
\text { other) }\end{array}$} & $\begin{array}{l}\text { Household contents } \\
\text { (main residence and } \\
\text { other) }\end{array}$ \\
\hline & \multicolumn{2}{|l|}{$\begin{array}{l}\text { Collectibles and } \\
\text { valuables }\end{array}$} & $\begin{array}{l}\text { Collectibles and } \\
\text { valuables }\end{array}$ \\
\hline & \multicolumn{2}{|l|}{ Trusts/Trust funds } & Net trust assets \\
\hline & \multirow{2}{*}{\multicolumn{2}{|c|}{$\begin{array}{l}\text { Business interests/ } \\
\text { Unincorporated business } \\
\text { equity }\end{array}$}} & Net business assets \\
\hline & & & \\
\hline & \multirow{2}{*}{\multicolumn{2}{|c|}{$\begin{array}{l}\text { Pension reserves/ } \\
\text { Superannuation/ } \\
\text { Retirement funds }\end{array}$}} & $\begin{array}{l}\text { Retirement funding } \\
\text { assets }\end{array}$ \\
\hline & & & \\
\hline & & Financial assets \\
\hline \multirow[t]{9}{*}{ Burial society } & Insurances & $\begin{array}{l}\text { Funeral, Special needs, } \\
\text { Education }\end{array}$ & $\begin{array}{l}\text { Insurance policies (in } \\
\text { sub classes) }\end{array}$ \\
\hline & \multicolumn{2}{|l|}{ Offshore investments } & Offshore investments \\
\hline & & Unlisted shares & Unlisted shares \\
\hline & & Loan accounts & Loan accounts \\
\hline & \multicolumn{2}{|l|}{$\begin{array}{l}\text { Bonds/government } \\
\text { bonds/debentures }\end{array}$} & Retail savings bonds \\
\hline & \multicolumn{2}{|l|}{ Employee shares } & Employee shares \\
\hline & \multicolumn{2}{|l|}{$\begin{array}{l}\text { Collective /Mutual } \\
\text { investments }\end{array}$} & Collective investments \\
\hline & & & Current assets \\
\hline & \multicolumn{2}{|l|}{ Debtors } & Debtors \\
\hline \multirow[t]{5}{*}{ Stokvels } & \multicolumn{2}{|l|}{ Savings/loan club } & Stokvels \\
\hline & \multicolumn{2}{|l|}{ Equity investments } & Listed shares \\
\hline & \multicolumn{2}{|l|}{ Fixed deposits } & Fixed deposits \\
\hline & \multicolumn{2}{|l|}{ Other financial assets } & Other \\
\hline & \multicolumn{2}{|l|}{ Saving accounts } & Saving accounts \\
\hline
\end{tabular}




\begin{tabular}{|c|c|c|c|}
\hline $\begin{array}{c}\text { Asset and liability } \\
\text { classes identified from } \\
\text { the national literature } \\
\text { review }\end{array}$ & $\begin{array}{l}\text { Asset and liability } \\
\text { classes identified from } \\
\text { the international } \\
\text { literature review }\end{array}$ & $\begin{array}{l}\text { Asset and liability } \\
\text { classes identified via } \\
\text { the focus groups } \\
\text { discussions }\end{array}$ & $\begin{array}{l}\text { Asset and liability } \\
\text { classes included to } \\
\text { measure South African } \\
\text { household net wealth }\end{array}$ \\
\hline & Money market accounts & & Money market accounts \\
\hline & Cheque accounts & & Cheque accounts \\
\hline Mzansiaccounts & & & Mzansiaccounts \\
\hline & Unbanked cash & & Cash at home \\
\hline \multicolumn{4}{|c|}{ LIABILITIES } \\
\hline & & & Mortgage loans \\
\hline & $\begin{array}{l}\text { Mortgage }(s) \text { - main } \\
\text { residence }\end{array}$ & & $\begin{array}{l}\text { Mortgage }(s) \text { - main } \\
\text { residence }\end{array}$ \\
\hline & $\begin{array}{l}\text { Mortgage }(s) \text { - other } \\
\text { properties }\end{array}$ & & $\begin{array}{l}\text { Mortgage }(\mathrm{s}) \text { - other } \\
\text { properties }\end{array}$ \\
\hline & & & Financial liabilities \\
\hline & Financing of vehicles & & $\begin{array}{l}\text { Financing of vehicles } \\
\text { (including boats and } \\
\text { planes) }\end{array}$ \\
\hline & $\begin{array}{l}\text { Instalment debt/Hire } \\
\text { purchase debt }\end{array}$ & & $\begin{array}{l}\text { Household content and } \\
\text { collectibles financing }\end{array}$ \\
\hline & & $\begin{array}{l}\text { Other hire purchase } \\
\text { agreements }\end{array}$ & $\begin{array}{l}\text { Other hire purchase } \\
\text { agreements }\end{array}$ \\
\hline & & Cell phone contracts & Cell phone contracts \\
\hline & Student loans & & Student loans \\
\hline & Personal loans & & Personal loans \\
\hline & Employer loans & & Employer loans \\
\hline & $\begin{array}{l}\text { Friend, relative, private } \\
\text { individual loans }\end{array}$ & & $\begin{array}{l}\text { Friend, relative, private } \\
\text { individual loans }\end{array}$ \\
\hline \multirow[t]{6}{*}{ Loan shark/mashonisha } & Cash loans & & Cash loans \\
\hline & Other loans & & Other loans \\
\hline & & & Current liabilities \\
\hline & $\begin{array}{l}\text { Bank overdraft/credit } \\
\text { lines }\end{array}$ & & Bank overdraft \\
\hline & Credit cards & & Credit cards \\
\hline & Store cards & & Store cards \\
\hline \multirow[t]{8}{*}{ Petrol and garage cards } & & & Petrol and garage cards \\
\hline & Municipal accounts & & Municipal accounts \\
\hline & & Airtime accounts & Airtime accounts \\
\hline & Rent in arrears & & Rent in arrears \\
\hline & & Alimony & Alimony \\
\hline & & School fees & School fees \\
\hline & & SABC, DStv/TopTV & SABC, DStv/TopTV \\
\hline & & Medical and related bills & Medical and related bills \\
\hline
\end{tabular}




\begin{tabular}{cccc}
\hline $\begin{array}{c}\text { Asset and liability } \\
\text { classes identified from } \\
\text { the national literature } \\
\text { review }\end{array}$ & $\begin{array}{c}\text { Asset and liability } \\
\text { classes identified from } \\
\text { the international } \\
\text { literature review }\end{array}$ & $\begin{array}{c}\text { Asset and liability } \\
\text { classes identified via } \\
\text { the focus groups } \\
\text { discussions }\end{array}$ & $\begin{array}{c}\text { Asset and liability } \\
\text { classes included to } \\
\text { measure South African } \\
\text { household net wealth }\end{array}$ \\
\hline & & Other household bills & Other household bills \\
\hline
\end{tabular}

Source: Scheepers (2014)

Although limited guidelines on micro-level net wealth measurement existed at the time of the study, the thought leadership of this study in developing this measurement instrument was, however, confirmed by the recently published Guidelines for Micro Statistics on Household Wealth $(0 \varepsilon C D, 2013)$. The publication provides guidance towards addressing the conceptual, definitional and practical problems that countries face when collecting micro-level household data estimates, and aims to improve data comparability within and among countries. The South African disaggregated asset and liability classes are therefore benchmarked against the 0ECD's suggested asset and liability categories to establish the instrument's authenticity. The benchmarking also includes the categories and classes from the NIDS survey to show this study's contribution towards South African disaggregated net wealth in TABLE 3. The main asset and liability categories of each survey are indicated in bold.

TABLE 3: Benchmarking the instrument's asset and liability typology with the suggested typology of the $0 \& C D$ guideline and the typology of the NIDS survey

\begin{tabular}{|c|c|c|}
\hline $\begin{array}{l}\text { Asset and liability typology } \\
\text { included in the South African } \\
\text { household net wealth } \\
\text { measurement instrument }\end{array}$ & $\begin{array}{c}\text { Recommended OECD asset and } \\
\text { liability typology }\end{array}$ & $\begin{array}{c}\text { NIDS typology of assets and } \\
\text { liabilities }\end{array}$ \\
\hline \multicolumn{3}{|c|}{ ASSET TYPOLOGY } \\
\hline Non-current assets & Non-financial assets & Real estate assets \\
\hline Main residence & Principal residence & Value of house \\
\hline Other property & $\begin{array}{l}\text { Other owner-occupied dwellings } \\
\text { Other real estate }\end{array}$ & Value of other property \\
\hline Other non-financial assets & Consumer durables & \\
\hline $\begin{array}{l}\text { Vehicles (including boats and } \\
\text { planes) }\end{array}$ & Vehicles & Value of vehicles \\
\hline $\begin{array}{l}\text { Household contents (main } \\
\text { residence and other) }\end{array}$ & Other consumer durables & \\
\hline Collectibles and valuables & $\begin{array}{l}\text { Valuables } \\
\text { Intellectual property and other } \\
\text { non-financial assets }\end{array}$ & \\
\hline Net trust assets & & \\
\hline Net business assets & $\begin{array}{l}\text { Net equity in own unincorporated } \\
\text { businesses (included with } \\
\text { financial assets) }\end{array}$ & $\begin{array}{l}\text { Business assets } \\
\text { Value of business assets }\end{array}$ \\
\hline Retirement funding assets & $\begin{array}{l}\text { Pension funds (included with } \\
\text { financial assets) } \\
\text { Social insurance pension funds }\end{array}$ & $\begin{array}{l}\text { Superannuation assets } \\
\text { Pension } \\
\text { Retirement annuity }\end{array}$ \\
\hline
\end{tabular}




\begin{tabular}{|c|c|c|}
\hline $\begin{array}{l}\text { Asset and liability typology } \\
\text { included in the South African } \\
\text { household net wealth } \\
\text { measurement instrument }\end{array}$ & $\begin{array}{c}\text { Recommended OECD asset and } \\
\text { liability typology }\end{array}$ & $\begin{array}{c}\text { NIDS typology of assets and } \\
\text { liabilities }\end{array}$ \\
\hline & Private pension funds & \\
\hline Financial assets & Financial assets & Financial assets \\
\hline Insurance policies (sub-classes) & Life insurance funds & Life insurance \\
\hline \multicolumn{3}{|l|}{ Offshore investments } \\
\hline Unlisted shares & Shares and other equity & \\
\hline \multicolumn{3}{|l|}{ Loan accounts } \\
\hline Retail savings bonds & Bonds and other debt securities & \\
\hline \multicolumn{3}{|l|}{ Employee shares } \\
\hline Collective investments & $\begin{array}{l}\text { Mutual funds and other } \\
\text { investment funds }\end{array}$ & \\
\hline \multicolumn{3}{|l|}{ Current assets } \\
\hline \multicolumn{3}{|l|}{ Debtors } \\
\hline \multicolumn{3}{|l|}{ Stokvels } \\
\hline Listed shares & $\begin{array}{l}\text { Shares in corporations (included } \\
\text { with shares and other equity) }\end{array}$ & Stocks \\
\hline Fixed deposits & Currency and deposits & \\
\hline Other & Other financial assets & \\
\hline \multicolumn{3}{|l|}{ Saving accounts } \\
\hline \multicolumn{3}{|l|}{ Money market accounts } \\
\hline Cheque accounts & & Bank account \\
\hline \multicolumn{3}{|l|}{ Mzansiaccounts } \\
\hline \multirow[t]{2}{*}{ Cash at home } & & Cash \\
\hline & & Live stock \\
\hline \multicolumn{3}{|c|}{ LIABILITY TYPOLOGY } \\
\hline Mortgage loans & Liabilities & Real estate debt \\
\hline Mortgage $(s)$ - main residence & Principal residence loans & Bond owing on main household \\
\hline \multirow[t]{3}{*}{ Mortgage(s) - other properties } & $\begin{array}{l}\text { Other owner-occupied residence } \\
\text { loans }\end{array}$ & Bonds owing on other properties \\
\hline & Other real estate loans & \\
\hline & & Home loans \\
\hline Financial liabilities & Consumer durable loans & \\
\hline $\begin{array}{l}\text { Financing of vehicles (including } \\
\text { boats and planes) }\end{array}$ & Vehicle loans & Vehicle finance \\
\hline \multirow{2}{*}{$\begin{array}{l}\text { Household content and } \\
\text { collectibles financing }\end{array}$} & Other consumer durable loans & \\
\hline & $\begin{array}{l}\text { Intellectual property and other } \\
\text { non-financial asset loan } \\
\text { (included in other investment } \\
\text { loans) }\end{array}$ & \\
\hline
\end{tabular}




\begin{tabular}{|c|c|c|}
\hline $\begin{array}{l}\text { Asset and liability typology } \\
\text { included in the South African } \\
\text { household net wealth } \\
\text { measurement instrument }\end{array}$ & $\begin{array}{c}\text { Recommended OECD asset and } \\
\text { liability typology }\end{array}$ & $\begin{array}{c}\text { NIDS typology of assets and } \\
\text { liabilities }\end{array}$ \\
\hline Other hire purchase agreements & $\begin{array}{l}\text { Other loans and liabilities } \\
\text { (included in consumer credit } \\
\text { loans and other liabilities) }\end{array}$ & \\
\hline \multicolumn{3}{|l|}{ Cell phone contracts } \\
\hline & & Business equity debt \\
\hline Student loans & $\begin{array}{l}\text { Education loans (included in } \\
\text { consumer credit loans and other } \\
\text { liabilities) }\end{array}$ & \\
\hline Personal loans & $\begin{array}{l}\text { Valuables loans (included in other } \\
\text { investment loans) }\end{array}$ & \\
\hline \multicolumn{3}{|l|}{ Employer loans } \\
\hline \multicolumn{3}{|l|}{$\begin{array}{l}\text { Friend, relative, private } \\
\text { individual loans }\end{array}$} \\
\hline Cash loans & $\begin{array}{l}\text { Financial asset loans (included in } \\
\text { other investment loans) }\end{array}$ & \\
\hline Other loans & Other investment loans & Loans \\
\hline \multicolumn{3}{|l|}{ Current liabilities } \\
\hline Bank overdraft & $\begin{array}{l}\text { Consumer credit loans and other } \\
\text { liabilities }\end{array}$ & \\
\hline \multicolumn{3}{|l|}{ Credit cards } \\
\hline \multicolumn{3}{|l|}{ Store cards } \\
\hline \multicolumn{3}{|l|}{ Petrol and garage cards } \\
\hline \multicolumn{3}{|l|}{ Municipal accounts } \\
\hline \multicolumn{3}{|l|}{ Airtime accounts } \\
\hline \multicolumn{3}{|l|}{ Rent in arrears } \\
\hline \multicolumn{3}{|l|}{ Alimony } \\
\hline \multicolumn{3}{|l|}{ School fees } \\
\hline \multicolumn{3}{|l|}{ SABC, DStv/TopTV } \\
\hline \multicolumn{3}{|l|}{ Medical and related bills } \\
\hline Other household bills & & \\
\hline
\end{tabular}

Source: Scheepers (2014); OECD (2013); Daniels et al. (2014)

\section{CONDUCTING A NATIONALLY REPRESENTATIVE HOUSEHOLD NET WEALTH SURVEY IN THE PUANTITATIVE STRAND}

The quantitative phase commenced with the piloting of an omnibus survey that incorporated the net wealth measurement instrument as the 'financial position section'. The omnibus survey is called the UNISA/Momentum Household Financial Well-being Survey and is used annually to conduct fieldwork among South African households to measure their disaggregated net wealth. 
Contributing to the usefulness of the survey, a household financial well-being index was developed to inform the general public via radio, television and newspapers of the results of the study.

A group of trained computer-aided telephonic interviewers were requested to pilot test the survey among each other, and each interviewer with one other willing respondent. In total, 38 completed interviews were received, whereafter limited adjustments to some sections were made.

Three data collection methods were incorporated, namely face-to-face interviews, telephonic interviews as well as the completion of an online survey, designed with the aid of SurveyMonkey software. The online survey was an attempt to include more of the high-income groups into the survey results, and was distributed to interested parties for completion using snowball sampling techniques (Tustin, Lighthelm, Martins, \& Van Wyk, 2005).

To ensure that the results were representative, the population included all households in South Africa. A sampling specialist of the BMR helped with the design of a comprehensive sample plan, which ensured that a representative sample of South African households was drawn randomly using probability sampling techniques. The sampling specialist built a sample frame from census information to control costs. The initial sample size was established at 2000 households and, according to the views of Tustin et al. (2005), is seen as sufficient. With the aid of a Monte Carlo simulation (Tustin et al, 2005) the sampling specialist ensured that households in all metropolitan and non-metropolitan municipalities across all nine provinces, inclusive of all four population groups, had an equal chance for inclusion in the sample. To minimise the imperfections of the sampling process such as bias, departures between the sample and the population, and unequal probabilities of selection, the sampling specialist tested and used rim-weighting to upweight the under-representative sampling units by 0.5 , and down-weighted those that were overrepresentative by 2.5 (Boniaszczuk, 2009). The sample was balanced by down-weighting the highest population group (African) and up-weighting the lowest group (Asian). The three least populated provinces (Free State, Mpumalanga and the Northern Cape) were up-weighted and the three most populated provinces (Eastern Cape, Gauteng, and KwaZulu-Natal) down-weighted (Scheepers, 2014). According to Lipovetsky (2007), sample balance is necessary in all social surveys to match the sample composition characteristics with that of the population.

The sample consisted of 2606 households, of which 1866 participated in face-to-face interviews, while 740 households were telephonically interviewed via the computer-aided telephonic interview system. The survey data was collected between August and November 2011. Apart from using a scientifically constructed sample frame, the following strategies were employed to reduce sampling and non-sampling errors, and to increase the validity and reliability of the data:

- The use of trained supervisors, interviewers and data capturers to reduce interviewing, coding and capturing errors.

- The supervisors employed call-back checking procedures and return visits to reduce nonresponse errors.

- They also performed field editing to ensure the comprehensive completion of the survey and the clarification of errors. The supervisors spot-checked telephonically to validate that the interviews were indeed conducted.

The data was centrally coded, edited, cleaned and weighed to the population by a statistician who also calculated the inter-correlations between education, labour status, income and total asset values to ensure that the data were consistent. Instead of expected high inter-correlations, low ones were found. The statistician constructed a coefficient index based on the inter- 
correlations, which was used to identify cases reflecting a significantly low level of consistency between the inter-correlations. The structural integrity, namely, the extent to which the variables in the dataset as a whole reflect previous validated research results, was subsequently investigated using neural networks.

The neural network analysis indicated the error term (linked to the percentage contribution) of the income variable specifically as a critical cause of the low initial $R$-square value. Hence, the expenditure variable from the omnibus survey served as a proxy for the latent income variable (Bollen, Glanville \& Stecklov, 2007:18; SARB, 2012:S112, S128). According to Masemola, Van Aardt, and Coetzee (2011:14), expenditure in a specific area and over a specific period closely tracks income. Furthermore, Bollen, Glanville, \& Stecklov (2007:18) contend that long-term considerations drive consumption, and household expenditure is therefore preferred to household income as a measure of long-term economic status. After considering the structural integrity of the cases, a final dataset of 1674 cases remained for analysis.

To be consistent with international studies (Antoniewicz, Bonci, Generale, Marchese, Neri, Maser \& O’Hagan, 2005; Dettling Sebastian, Devlin-Foltz, Pack \& Thompson, 2015; Honkkila \& Kavonius, 2013; Kavonius \& Honkkila, 2013; Kavonius \& Törmälehto, 2010; 0ECD 2013; Sierminska, Brandolini $\&$ Smeeding, 2006), the researchers explored the conceptual linkages and differences between the survey data estimates and the only other South African net wealth data source available at the time - the SARB household balance sheet data estimates for 2011. Valid conclusions from the disaggregated micro-level data estimates can be made only if there are linkages to the central bank's macro-level data estimates.

\section{EXPLORATION OF CONCEPTUAL LINKAGES AND DIFFERENCES BETWEEN MICRO-LEVEL AND MACRO-LEVEL DATA ESTIMATES}

In order to determine whether the survey data estimates, which are presented in section 8 , were comparable to the household balance sheet data estimates from national accounts, it was necessary to ensure that the two measures could be linked on a conceptually equivalent basis. The process of establishing such conceptual linkages can be summarised as follows (Antoniewicz et al., 2005; Dettling et al., 2015; Honkkila \& Kavonius, 2013; Kavonius \& Honkkila, 2013; Kavonius \& Törmälehto, 2010; Sierminska et al., 2006):

- Determine whether operational concepts are comparable. A detailed discussion is provided in section 7.1;

- As the two sets of data estimates were produced by two different mechanisms, the influence of the mode of production must be understood. Timing differences had to be considered because the two sets of data estimates were in all likelihood not compiled at the same point in time. This is discussed in section 7.2; and

- The influence of certain potential errors during the collection of survey data should be recognised. A detailed discussion is provided in section 7.3 .

\subsection{Operational concepts}

Operational concepts refer, firstly, to the definition of the household as a survey unit, and secondly, to the typologies of assets and liabilities and their respective measurement. 
In the SNA (UN et al., 2009:61), a 'household' is defined as 'a group of persons who share the same living accommodation, who pool some, or all, of their income and wealth and who consume certain types of goods and services collectively, mainly housing and food'. In essence, the difference in the household definition of the survey and the SNA can be summarised as the inclusion of household members based on a wealth creation perspective, as per the household survey, when compared to a living condition perspective, as per national accounts. The 'household' as defined in section 5.2, includes all members that are considered in the long-term financial planning of the unit, irrespective of residence. Thus, in the case of a migrant worker who, for example, works in the North-West province and transfers the bulk of his earnings to the Eastern Cape where his family resides, the migrant worker and his family would be deemed as one household for purposes of the survey. However, in terms of the national accounts perspective, the migrant worker and his family would be deemed to be two separate households. In addition to the definitional differences and as reported by Antoniewicz et al. (2005), Honkkila and Kavonius (2013), Kavonius and Honkkila (2013) and Kavonius and Törmälehto (2010), the household sector balance sheet also includes information about institutional units such as non-corporate or quasi-corporate firms, as well as the non-profit institutions serving households. This is not included in the survey data estimates.

To establish linkages and differences in terms of the typology of assets and liabilities and their respective measurement in the two sets of data estimates, it was necessary to firstly describe the compilation and measurement of the data estimates produced by the SNA, and secondly, to classify the survey estimates similarly to the SNA's main asset and liability categories. TABLE 4 is a summary of the compilation of the SNA data estimates and the corresponding classification of the survey's asset and liability typology to enable comparison after alignment:

TABLE 4: Compilation of the SARB assets and liabilities versus the classification of household survey assets and liabilities to align with the macro-level data

\begin{tabular}{|c|c|}
\hline $\begin{array}{l}\text { Compilation of SARB household } \\
\text { assets and liabilities }\end{array}$ & $\begin{array}{l}\text { UNISA/Momentum survey assets and liabilities } \\
\text { classified to align with SARB main categories }\end{array}$ \\
\hline Non-financial assets & Non-financial assets \\
\hline Residential buildings include: & Residential buildings include: \\
\hline $\begin{array}{l}\text { Capital stock at constant prices calculated according } \\
\text { to the perpetual inventory method (PIM), inflated by } \\
\text { an average house price index. Land value is a ratio of } \\
\text { the housing value. }\end{array}$ & $\begin{array}{l}\text { Market value of residential property and other } \\
\text { properties. }\end{array}$ \\
\hline Other non-financial assets include: & Other non-financial assets Include: \\
\hline $\begin{array}{l}\text { - Non-residential buildings and non-residential land } \\
\text { estimated indirectly and similarly to residential } \\
\text { buildings. Land value is derived indirectly as a ratio } \\
\text { of the value of non-residential buildings. } \\
\text { - Construction work, machinery and equipment, } \\
\text { computer equipment, transport equipment and } \\
\text { orchards. Compiled from unpublished estimates of } \\
\text { replacement value (as proxy for market value) } \\
\text { obtained from capital stock (using PIM). } \\
\text { Unpublished annual estimates of the market value } \\
\text { of agricultural land are used. }\end{array}$ & $\begin{array}{l}\text { Market value of boats, planes, content, collectibles } \\
\text { and valuables, vehicles, net business and trust assets. }\end{array}$ \\
\hline
\end{tabular}




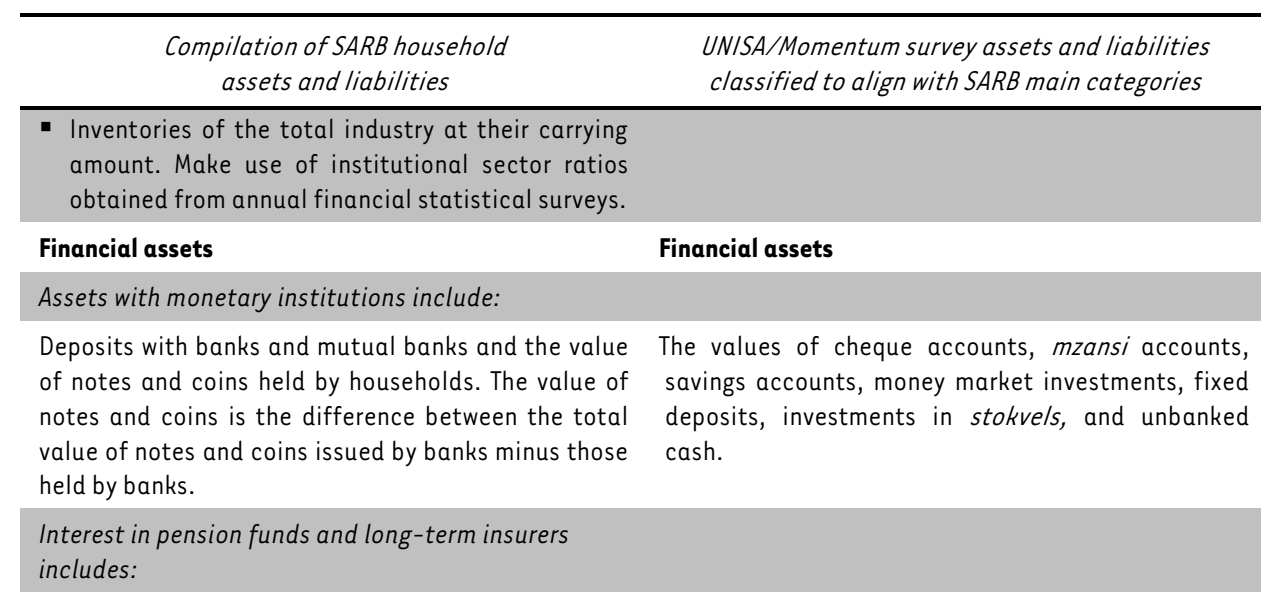

- Investment in official and private selfadministered pension and provident funds. The values are obtained from returns submitted by institutions.

- The investment in long-term insurance. The values of existing policies from long-term insurance are directly surveyed from the institutions.

\section{Other financial assets include:}

- Investment in government and public entities stock obtained from flow of funds data at revalued amounts. Deposits in participating mortgage bond schemes are calculated from counterpart data.

- Collective investment schemes. Published market values.

- Corporate bonds and equities. Valued according to Johannesburg Securities Exchange (JSE) all-share index adjusted for trading and management costs. The households' share is calculated from the flow of funds.

- Other long-term deposits include deposits with non-financial entities and are obtained from flow of funds.

- The household sector investment in foreign assets. The value is obtained from the balance of payment division.

\section{Liabilities}

\section{Mortgage advances include:}

Loan financing from the commercial banking sector. Mortgage values for residential and other properties The value is obtained from monthly returns from the banks.

\section{Other debt include:}

- Trade credit (open account credit). This includes retail debt and amounts owing to buy-aid institutions. Compiled indirectly from retail credit sales information.
Collective investment values, retail savings bonds, listed and unlisted share values, employee share scheme values, loan accounts in businesses and trusts, debtors, offshore assets/investments and other financial assets
The values of pension fund assets, funeral policies, specific needs policies, education policies, burial society policies.

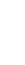




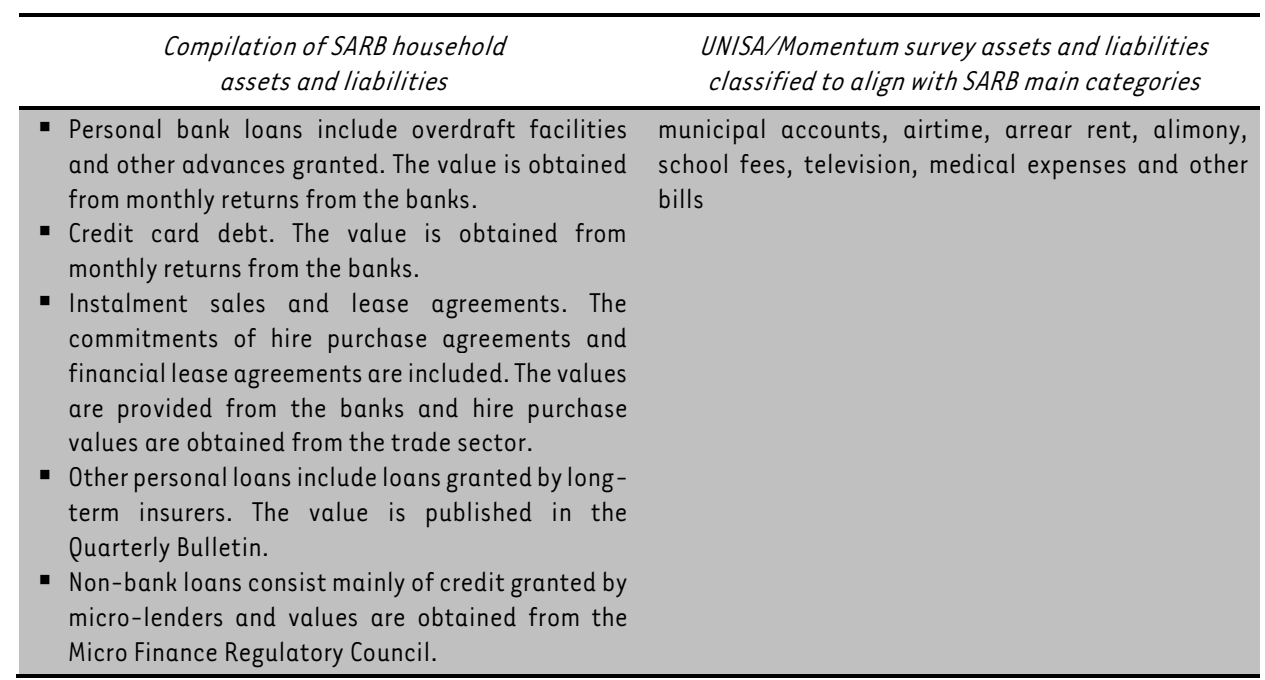

Source: Kuhn (2010), Walters and national accounts division (2011) and Scheepers (2014)

It is apparent from TABLE 4 that for South Africa, conceptual linkages between certain categories exist and are therefore comparable: for example, the composition and measurement concepts of financial assets and liabilities are similar. However, alignment at the component or class level would require special estimation and modelling techniques to enable comparison. Conversely, there are also certain categories where the data sources and measurement concepts differ fundamentally. According to the $0 \varepsilon C D$ (2013:55-63), significant differences in classification relate mostly to non-financial assets. This lack in linkage is also apparent in TABLE 4 . In terms of the national accounts data set, residential property and other non-financial assets are reported at constant prices, and adjusted with an average house price index, which is fundamentally different to the market values reported in the household survey.

\subsection{Production methods}

Production methods were mentioned in section 7 as one of the main reasons for differences between the two sets of data estimates. The SARB used macro-data estimates, which is the end result of a quarterly integrated accounting system (Kuhn, 2010; Walters \& National Accounts Division, 2011), whereas the survey obtained micro-data estimates directly from household respondents.

The statistical coverage of national accounts data estimates and the coverage of households in the sample also impeded full alignment (OECD, 2013:55-63). Similarly, timing differences in the collection of data between the two sets of data estimates contributed to differences. This is especially troublesome for financial instruments where values change over a short period of time (Antoniewicz et al., 2005; Kavonius \& Törmälehto, 2010). Data collection in household surveys is time consuming, ranging from three to eighteen months (depending on the sample size). Contradictory to this is the reporting of values in national accounts on a specific date. In an attempt to address the issue, the respondents were requested to provide estimates of values as at 31 December 2011 to correspond with the macro-level estimates of the SARB. 


\subsection{Typology of errors}

Errors that occurred during the collection of the survey data estimates further contributed to discrepancies between the two sets of estimates. The researchers agree with the typology of errors mentioned by Honkkila and Kavonius (2012), and Kavonius and Törmälehto (2010), which comprise errors in estimation and in measurement. According to Kavonius and Törmälehto (2010:6-7), and Honkkila and Kavonius (2012:15), 'errors in estimation are errors in the extrapolation from the household enumerated in the survey to the entire population of private households for which estimates are required' whereas 'errors in measurement occur when a value recorded for a household in the sample departs from the actual true value for the household'.

Errors in estimation normally originate from errors in the coverage of the realised sample. If the target population differed from the sample frame, or the potential respondents did not have a random non-zero probability to be selected for participation, the extrapolation of the survey results to the population would not have been achieved. The study incorporated strategies to include high net worth households in the form of an online survey due to knowledge about the traditionally low response rate of these households. The study also employed sample balance through weight adjustments to address errors in estimation. Kavonius and Törmälehto (2010) and Honkkila and Kavonius (2012) support the idea of using sample weights to eliminate overcoverage, enabling multiple selection probabilities, and assisting calibration.

Errors in measurement may occur for to a variety of reasons, or as a result of actions taken by either the respondents or the fieldwork team. In terms of the respondents, errors may occur when the respondent misinterprets the question, the result of which is either an unwillingness to answer the question or leaving the respondent unable to answer the question. The fieldworker may also misunderstand the question if the operational concepts were unclear or training was insufficient. To mitigate the risk of non-response errors, conceptual definitions were documented in the training manual and explained to the interviewers and field-supervisors during training. These mitigations however, may not necessarily eliminate these errors. In addition to non-response errors, under-reporting is another error in measurement that could occur (Honkkila \& Kavonius, 2012; Kavonius \& Törmälehto, 2010). Respondents may not be able to recall the actual value of the item in question and thereby provide an 'educated guess' of the value or may even deny that the household in fact owns/owes such an asset/liability. Unfortunately, no extent of training can mitigate this error type. Honkkila and Kavonius (2012) also emphasised the importance of survey mode in limiting capturing errors during fieldwork. The technological improvement and diminished costs in computer equipment sustain the argument for data collection via computer-assisted personal interviews, budget permitting. It allows for easier routing of questions, as the logic of the questionnaire can be pre-programmed to eliminate questions about assets and liabilities not owned or owed by households. Certain consistency checks can also be pre-programmed to alert fieldworkers to missing data during the interview process, and correction can then be done instantaneously. Using computer-based technology allows information to be uploaded via a cloud-based platform to a central database without time delays. This ensures that the data can be collated from various fieldwork stations to get a collective view on the realised sample and also ensures automatic storage of the data (Honkkila \& Kavonius, 2012; $\varepsilon C B, 2008$ ). Due to budget constraints, limited use of technological improvements was incorporated in the first data collection phase.

While the limitations of the disaggregated data estimates collected in the study are recognised and acknowledged, this should not detract from the usefulness and importance of having disaggregated household net wealth data available. Disaggregated net wealth data allows for 
analyses of the composition and distribution of net wealth across different households and contributes towards the management of household financial well-being.

\section{RESULTS AND DISCUSSION}

This section presents the survey data estimates from the first collection phase in TABLE 5. The survey data estimates are classified according to the categories presented in TABLE 4 . This section also presents the main asset and liability categories of the SARB household balance sheet in TABLE 5. A comparison with the central bank's corresponding macro-level household data as at 31 December 2011 (SARB, 2012) was necessary to validate the results (OECD, 2013). The table also presents the percentage of the micro-level estimate relative to the macro-level estimate for each main asset and liability category (Antoniewicz et al., 2005). Thus, perfectly aligned micro- and macro-level estimates would have a figure of $100 \%$. A figure below $100 \%$ indicates that the microlevel estimate is below (undervalued) the macro-level estimate, while a figure above $100 \%$ indicates that the micro-level estimate is higher (overvalued) than the macro-level estimate.

The difference between the SARB macro-data estimates (net wealth R5 969 billion) and the results of the household micro-data (net wealth R6 830 billion) is an indication of the differences in operational concepts, production methods, and errors. Apart from these differences, Bollard, Hodgetts, Briggs and Smith (2006:9) also mentioned that surveys tend to over-or underestimate the overall assets and liabilities; however, the results of these surveys should be viewed as indicative estimates rather than definitive measures. The differences should rather be viewed in the light of the different methodology applied and the best estimate of asset and liability values provided by respondents.

The micro-level estimates for total assets aligned fairly well with the macro-level estimates thereof, and were only slightly higher at $101 \%$. However, alignment diminished in the different asset categories, with non-financial assets at $172 \%$, other non-financial assets at $149 \%$, and pension fund and insurance assets at $108 \%$ of their macro-level estimates. Aside from the mentioned explanations, one plausible explanation could be an upward bias because households estimate the value of their assets higher than at fair market value. Despite over-estimation probability, assets with monetary institutions and other financial assets were only $36 \%$ and $18 \%$, respectively, of the value of the macro-level estimates. This could be a direct result of the lack of access to wealthier households who would make more use of these asset types, especially share investments.

What is concerning, however, is the low micro-level debt estimate levels provided by the responding households. Mortgage bonds and other debt were measured at $36 \%$ and $52 \%$, respectively, of the macro-level estimates and total liabilities at micro-level at $43 \%$ of the macro-level estimates. The low micro-level debt estimation could also be ascribed to production methods and errors in measurement. In addition, the limited access to high-income households could have contributed greatly given that higher debt levels are usually associated with higher income levels and higher income levels are prerequisites for qualifying for mortgages, loans and other financing options. It could also be that the presence of the interviewers made the household FKP reluctant to record the true debt levels of the household. The low debt estimation also indicates that the attempt to include higher income households by way of an online survey was less successful than originally expected. 
TABLE 5: South African Reserve Bank household macro-level data compared to the UNISA/Momentum survey's micro-level data

(R Billion / Percentages of micro estimates relative to macro estimates)

\begin{tabular}{|c|c|c|c|}
\hline $\begin{array}{l}\text { Assets/Liability SARB main categories } \\
\text { Disaggregated asset and liability classes }\end{array}$ & $\begin{array}{c}\text { SARB data } \\
\text { estimates } \\
R \text { billion }\end{array}$ & $\begin{array}{c}\text { UNISA/ } \\
\text { Momentum } \\
\text { Survey } \\
\text { estimates } \\
\text { Rbillion }\end{array}$ & $\begin{array}{c}\text { Percentage } \\
\text { relative to } \\
\text { SARB } \\
\text { estimates } \\
\%\end{array}$ \\
\hline Residential buildings / Non-financial assets & 1716 & 2954 & 172 \\
\hline Residential property & & 2472 & \\
\hline Other property & & 482 & \\
\hline $\begin{array}{l}\text { Durable consumer goods / Other non-financial } \\
\text { assets }\end{array}$ & 771 & 1152 & 149 \\
\hline Vehicles & & 475 & \\
\hline Household content & & 412 & \\
\hline Collectibles and valuables & & 91 & \\
\hline Trust assets & & 6 & \\
\hline Business assets & & 168 & \\
\hline Financial assets & 4847 & 3305 & 68 \\
\hline Assets with monetary institutions & 637 & 230 & 36 \\
\hline Cheque accounts & & 93 & \\
\hline Mzansi accounts & & 4 & \\
\hline Savings accounts & & 30 & \\
\hline Money market accounts & & 60 & \\
\hline Fixed deposits & & 22 & \\
\hline Stokvels & & 18 & \\
\hline Cash at home & & 3 & \\
\hline Interest in pension funds and long-term insurers & 2584 & 2784 & 108 \\
\hline Other financial assets & 1626 & 291 & 18 \\
\hline Collective investments & & 61 & \\
\hline Retail savings bonds & & 10 & \\
\hline Listed shares & & 78 & \\
\hline Unlisted shares & & 14 & \\
\hline Employee shares & & 32 & \\
\hline Offshore assets & & 19 & \\
\hline Loan accounts & & 4 & \\
\hline Debtors & & 2 & \\
\hline Other & & 71 & \\
\hline TOTAL ASSETS (A) & 7334 & 7411 & 101 \\
\hline
\end{tabular}




\begin{tabular}{|c|c|c|c|}
\hline $\begin{array}{l}\text { Assets/Liability SARB main categories } \\
\text { Disaggregated asset and liability classes }\end{array}$ & $\begin{array}{c}\text { SARB data } \\
\text { estimates } \\
R \text { billion }\end{array}$ & $\begin{array}{l}\text { UNISA/ } \\
\text { Momentum } \\
\text { Survey } \\
\text { estimates } \\
\text { Rbillion }\end{array}$ & $\begin{array}{c}\text { Percentage } \\
\text { relative to } \\
\text { SARB } \\
\text { estimates } \\
\%\end{array}$ \\
\hline TOTAL LIABILITIES (B) & 1365 & 581 & 43 \\
\hline Mortgage advances & 793 & 285 & 36 \\
\hline Mortgage on residential property & & 271 & \\
\hline Mortgages on other property & & 14 & \\
\hline Other debt & 572 & 296 & 52 \\
\hline Debt on vehicles & & 165 & \\
\hline Bank overdraft & & 7 & \\
\hline Credit cards & & 22 & \\
\hline Store cards & & 15 & \\
\hline Petrol/Garage cards & & 1 & \\
\hline Student loans & & 6 & \\
\hline Personal loans & & 20 & \\
\hline Cash loans & & 5 & \\
\hline Loan from an employer & & 2 & \\
\hline Loan from a friend, relative or private & & 2 & \\
\hline Hire purchases & & 3 & \\
\hline Cell phone contracts & & 6 & \\
\hline Municipal accounts & & 8 & \\
\hline Airtime accounts & & 1 & \\
\hline Outstanding rent payments & & 2 & \\
\hline Outstanding school fees & & 27 & \\
\hline Outstanding SABC/DStv/TopTV & & 2 & \\
\hline Outstanding medical bills & & 1 & \\
\hline Other outstanding bills & & 1 & \\
\hline NET WEALTH (A-B) & 5969 & 6830 & 114 \\
\hline
\end{tabular}

Source: SARB (2012); Scheepers (2014)

Although macro-level estimates for pension assets closely aligned with the micro-level estimates at $108 \%$, caution must be exercised when interpreting pension assets. The respondents did not complete this asset class comprehensively, which resulted in reporting bias. This was verified by the statistician during the validity and structural integrity tests, as mentioned in section 6 . This is not unusual, as the contentious nature of pension asset estimation is also experienced in international studies (Black, 2011; Carasso \& McKerman, 2007; 0ECD, 2013).

Flowing from the results and discussion, the task of comparing and reconciling micro- and macrolevel data was both ambitious and difficult. The objective of the data linkage discussion and speculating about the reasons for any differences was a modest attempt to present the challenges of household net wealth measurement. The discussions provided a better perspective on the quality implications of the direct and indirect data collection methods used. 


\section{CONCLUSION}

In this article, a mixed methods approach to collecting household net wealth data was described. The development of a South African net wealth measurement instrument, which was able to disaggregate and measure assets and liabilities at micro-level, was presented. Using a mixed methods approach could assist other developing countries that are interested in net wealth measurement to develop a robust country-specific measurement instrument. A similar context for the use of mixed methods research could not be found. The appropriateness and value of a qualitative as well as a quantitative strand proved to be advantageous and can be incorporated in most survey designs. This implies that household net wealth measurement can be accomplished by incorporating a household net wealth section at minimal cost into existing Living Conditions Surveys.

Although the results from the survey are subject to the general limitations of survey methodology, as discussed in section 7, this research contributes to South African household data and knowledge, which was not yet available at the time of this study. Disaggregating data on the asset and liability base of households is a crucial step forward towards countrywide net wealth management. Previous South African household research focused mainly on measuring the income and expenditure patterns of households. Although the contribution of these studies cannot be underrated, knowledge about income and expenditure provides only a narrow view of household financial well-being. Viewing information of a household's financial position, together with income and expenditure, gives a broad overview of its financial well-being.

The methodology and definitions used to prepare national accounts for households using macroeconomic estimates differ from those used to collect survey data. A comparison of the two data sets lays the foundation for future articles, which present compositional and distributional data from the survey. Future research endeavours to align the two sources more closely are, however, necessary. Given the cursory findings in this article, one recommendation for future work is to extend the reconciliation and comparison effort to include the comparison results from other countries. Disaggregated household net wealth data can also be used in future trend and distribution analyses. Further possible research niche areas are: 1) Factors affecting the financial behaviour of households and their importance in ensuring a healthy environment for increasing household net wealth; 2) Determining the underlying factors that influence household financing decisions; and 3) The use of government policy to change households' financial behaviour.

Finally, the disaggregated asset and liability base could assist with the analysis of consumption and saving patterns, as well as all associated variations in the debt levels of households. It could also provide valuable insights into household asset and liability accumulation, and the socioeconomic imbalances of the country. Future longitudinal data estimates from the survey and the results from other household studies could provide government, household net wealth experts, and other interested parties with the means to track their reform goals and identify target groups based on research results, and not merely on conjecture or political expediency.

\section{LIST OF REFERENCES}

ABS (Australian Bureau of Statistics). (2011). Household wealth and wealth distribution, Australia 2009-2010. Available: http://www.abs.gov.au/AUSSTATS/abs@.nsf/DetailsPage/6554.02009-10. Accessed 12 December 2011). 
Antoniewicz, R., Bonci, R., Generale, A., Marchese, G., Neri, A., Maser, K. \& O’Hagan, P. (2005). Household Wealth: Comparing Micro and Macro Data in Cyprus, Canada, Italy and United States, LWS Workshop: Construction and Usage of Comparable Micro data on Wealth: the LWS, Banca d'Italia, Perugia, Italy, 27-29 January 2005. Available:

https://www.researchgate.net/publication/275338312HOUSEHOLD_WEALTH_COMPARING_MICRO_AND _MACRO_DATA_IN_CYPRUS_CANADA_ITALY_AND_UNITED_STATES (Accessed 17 February 2016).

Aron, J., Muellbauer, J. \& Prinsloo, J. (2006). Estimating household-sector wealth in South Africa. Quarterly Bulletin, No. 240, June.

Aron, J., Muellbauer, J. \& Prinsloo, J. (2007). Balance sheet estimates for South Africa's household sector from 1975-2005. Pretoria: South African Reserve Bank.

Barth, M.E. (2008). Global financial reporting: Implications for US academics. The Accounting Review, 83(5), pp. 1159-1179.

Bhorat, H., Van der Westhuizen, C. \& Cassim, A. (2009). Access to household services and assets: Analysis using the NIDS Wave I dataset. Cape Town: National Income Dynamics Study.

Black, 0. (2011). Wealth in Great Britain: main results from the Wealth and Asset Survey: 2008/10. Newport: Office of National Statistics.

Bloxham, P. \& Betts, T. (2009). Measures of household wealth for Australia. The Australian Economic Review, 42(2), pp. 217-231.

Bollard, A., Hodgetts, B., Briggs, P. \& Smith, M. (2006). Household savings and wealth in New Zealand. Reserve Bank of New Zealand.

Bollen, K.A., Glanville, J.L. \& Stecklov, G. (2007). Socio-economic status, permanent income, and fertility: a latent-variable approach. Population Studies, 61(1), pp.15-34.

Boniaszczuk, J. (2009). Death of the analyst: the case for data calibration and advanced weighting. Cape Town: SAMRA.

Bover, 0. (2008). The Spanish Survey of Household Finances (EFF): description and methods of the 2005 wave. Madrid: Banco De Espana.

Bricker, J., Bucks, B., Kennickell, A., Mach, T. \& Moore, K. (2011). Surveying the aftermath of the storm: Changes in family finances from 2007-2009. Finance and Economic Discussion Series. Washington, DC: Federal Reserve Board.

Brown, M., Daniels, R.C., De Villiers, L., Leibbrandt, M. \& Woolard, I. (2012). National Income Dynamics Study Wave 2 Beta Release User Manual. Cape Town: South African Labour and Development Research Unit.

Campbell, J.Y. (2006). Household finance. The Journal of Finance, 61 (4), pp. 1553-1604.

Carasso, A. \& McKerman, S. (2007). The balance sheets of low-income households: what we know about their assets and liabilities. Washington, DC: Office of the Assistant Secretary for Planning and Evaluation, US Department of Health and Human Services.

Case, K.E., Fair, R.C. \& Oster, S.M. (2009). Principles of economics, $9^{\text {th }}$ edition. Upper Saddle River, NJ: Pearson Prentice Hall.

Creedy, J. \& Tan, L. (2007). The relationship between personal income and net worth in Australia. The Australian Economic Review, 40(2), pp. 165-181. 
Creswell, J.W. \& Plano Clark, V.L. (2011). Designing and conducting mixed methods research, $2^{\text {nd }}$ edition. Thousand Oaks, CA: Sage.

Daffin, C. (2009). Wealth in Great Britain: main results from the Wealth and Assets Survey: 2006/08. Newport: Office for National Statistics.

Daniels, R.C., Finn, A. \& Musundwa, S. (2014). Wealth data quality in the National Income Dynamics Study Wave 2, Development Southern Africa, 31(1), pp. 31-50.

Deegan, C. (2010). Financial accounting theory, 3rd edition. Sydney: McGraw-Hill Australia.

Dettling, L.J., Sebastian, J., Devlin-Foltz, J.K., Pack, S.J. \& Thompson, J.P. (2015). Comparing Micro and Macro Sources for Household Accounts in the United States: Evidence from the Survey of Consumer Finances. Finance and Economics Discussion Series 2015-086. Washington: Board of Governors of the Federal Reserve System. Available: http://dx.doi.org/10.17016/FEDS.2015.086. (Accessed 18 February 2016).

Edmeades, J., Nyblade, L., Malhotra, A., MacQuarrie, K., Parasuraman, S. \& Walia, S. (2010). Methodological Innovation in Studying Abortion in Developing Countries: A "Narrative" Quantitative Survey in Madhya Pradesh, India. Journal of Mixed Methods Research, 4(3) pp.176-198.

European Central Bank/Household Finance and Consumption Network (ECB/HFCN). (2009). European Central Bank and Household Finance and Consumption Network. Available:

http://www.ecb.int/home/html/researcher_hfcn.en.html (Accessed 6 June 2011).

Finmark Trust. (2010). FinScope South Africa 2010: From a livelihood approach towards a FinScope Sustainability Model. Pretoria: Finmark Trust.

Fourie, F.C. \& Burger, P. (2011). How to think and reason in macroeconomics, $3^{\text {td }}$ edition. Claremont: Juta.

Headey, B., Marks, G. \& Wooden, M. (2005). The structure and distribution of household wealth in Australia. The Australian Economic Review, 38(2), pp. 159-175.

Honkkila, J. \& Kavonius, I.K. (2012). Micro and Macro Analysis on Household Income, Wealth and Saving in the Euro Area. Proceedings of the $32^{\text {nd }}$ General Conference of the International Association for Research in Income and Wealth (IARIW), Boston, USA, August 5-11, 2012. Available: http://www.iariw.org/papers/2012/KavoniusPaper.pdf. (Accessed 10 February 2016).

Honkkila, J. \& Kavonius, I.K. (2013). Micro and Macro Analysis on Household Income, Wealth and Saving in the Euro Area. European Central Bank, Working Paper Series No 1619. Frankfurt am Main.

Husband, G.R. (1954). The entity concept in accounting. The Accounting Review, 29 (4), pp. 552-563.

IHSN (International Household Survey Network). (2001). Department of Statistics, Republic of Moldova 2001 Household Budget Survey. Available:

http://www.ihsn.org/home/?q=country_questionnnaires (Accessed 7 July 2011).

IHSN (International Household Survey Network). (2006). Turkey, 2006, Household Budget Survey Available: http://www.ihsn.org/home/?q=country_questionnaires (Accessed 7 July 2011).

Jantti, M., Sierminska, દ. \& Smeeding, T. (2008). The joint distribution of household income and wealth: evidence from the Luxembourg Wealth Study. Portoroz: International Association for Research in Income and Wealth.

Johnson, R.B. \& Onwuegbuzie, A.J. (2004). Mixed Methods Research: A Research Paradigm Whose Time Has Come. Educational Researcher, 33(7), pp.14-26. 
Kavonius, I.K. \& Törmälehto, V.M. (2010). Integrating Micro and Macro Accounts - The Linkages Between Euro Area Household Wealth Survey and Aggregate Balance Sheets for Household, Proceedings of the IARIW $31^{\text {st }}$ General Conference, St-Gallen, Switzerland, 22-28 August 2010.

Kavonius, I.K. \& Honkkila, J. (2013). Reconciling Micro and Macro Data on Household Wealth: A test based on three Euro Area Countries. Journal of Economic and Social Policy, 15(2), pp. 1-30.

Kennickell, A.B. (2000). Wealth measurement in the Survey of Consumer Finances: Methodology and directions for future research. Washington, DC: Federal Reserve Board.

Kennickell, A.B. (2009). Ponds and streams: wealth and income in the US, 1989-2007. Finance and Economics Discussion Series. Washington, DC: Federal Reserve Board.

Kuhn, K. (2010). Note on household wealth in South Africa. Quarterly Bulletin, No. 257, September.

Le, T., Gibson, J. \& Stillman, S. (2010). Household wealth and saving in New Zealand: Evidence from the Longitudinal Survey of Family, Income and Employment. Melbourne: Motu Economic and Public Policy Research.

Li, S. \& Zhao, R. (2007). Changes in the distribution of wealth in China: 1995-2002. Helsinki: UNUWIDER.

Lipovetsky, S. (2007). Post-stratification with optimized effective base: linear and non-linear ridge regression approach. Available:

http://www.amstat.org/sections/srms/proceedings/y2007/Files/JSM2007-000339.pdf. (Accessed 30 August 2011).

Malpezzi, S. (2000). ‘Housing'. In Grosh, M. \& Glewwe, P. (eds.) Designing household survey questionnaires for developing countries. Volume 1. Washington, DC: World Bank. pp. 293-314.

Masemola, M.E., Van Aardt, C.J. \& Coetzee, M.C. (2011). Income and expenditure of households in South Africa, 2011. Pretoria: Bureau of Market Research.

OECD (Organisation for Economic Co-operation and Development). (2013). OECD Guidelines for Micro Statistics on Household Wealth, OECD Publishing. Available:

http://dx.doi.org/10.1787/9789264194878-en. (Accessed 14 November 2014).

Onwuegbuzie, A.J. \& Leech, N.L. (2006). Linking Research Questions to Mixed Methods Data Analysis Procedures. The Qualitative Report, 11(3), pp. 474-498.

Onwuegbuzie, A.J., Bustamante, R.M. \& Nelson, J.A. (2010). Journal of Mixed Methods Research, 4(1), pp. 56-78.

Riahi-Belkaoui, A. (2004). Accounting theory, 5th edition. Chicago, IL: Thomson.

RAND Family Life Surveys. (2007). The Indonesian Family Life Survey (IFLS) Available:

http://www.rand.org/labour/FLS/IFLS.html. (Accessed 13 March 2012).

SAARF (South African Audience Research Foundation). (2010). All Media and Product Survey $2010 B$ [Database]. Pretoria: BMR.

SAICA (South African Institute of Chartered Accountants). (2014a). "The conceptual framework for financial reporting." In International Financial reporting standards: A Guide through IFRS: Part Al. London: IFRS Foundation, pp. Al3-A44.

SAICA (South African Institute of Chartered Accountants). (2014b). "Presentation of Financial Statements." In International Financial reporting standards: A Guide through IFRS: Part A2. London: IFRS Foundation, pp. A745-A791. 
Samphantharak, K. \& Townsend, R.M. (2008). Households as corporate firms: constructing financial statements from integrated household surveys. San Diego, CA: Graduate School of International Relations and Pacific Studies.

Sanchez-Munoz, C. \& Tzamourani, P. (2008). Developing the questionnaire for the Eurosystem Survey on Household Finance and Consumption. Rome: Eurosystem Household Finance and Consumption Network.

SARB (South African Reserve Bank). (2012). Quarterly Bulletin, No. 265, September.

SARB (South African Reserve Bank). (2014). Quarterly Bulletin, No. 274, December.

SC (Statistics Canada). (2010). User guide for the Survey of Household Spending. Available: http://wwwstatcan.gc.ca. (Accessed 12 December 2011).

Sierminska, E., Brandolini, A. \& Smeeding, T.M. (2006). Comparing wealth distribution across rich countries: first results from the Luxembourg Wealth Study. Luxembourg Income Study (LIS): Luxembourg Wealth Study Working Paper Series, Working Paper 1.

SSA (Statistics South Africa). (2010). Profiling South African middle-class households: 1998-2006. Available: http://www.statssa.gov.za/publications/statsdownload.asp?PPN=Report-03-03-01 (Accessed 30 November 2011).

SSA (Statistics South Africa). (2011a). General Household Survey: 2011 Available: http://www.statssa.gov.za/Publications/statsdownload.asp?PPN=P0318 (Accessed 27 November 2012).

SSA (Statistics South Africa). (2011b). General Household Survey (GHS) 2010. Available: http://www.statssa/publications/statsdownload.asp?PPN=P0318\&SCH=4912. (Accessed 29 November 2011).

SSA (Statistics South Africa). (2011c). Living conditions of households in SA 2008/09. Available: http://www.statssa.gov.za/publications/statsdownload.asp?PPN=P0310\&SCH=5017. (Accessed 30 November 2011).

SSA (Statistics South Africa). (2011d). Stats online Income and Expenditure Survey. Available: http://www.statssa.gov.za/ies/welcome.asp. (Accessed 30 November 2011).

SSA (Statistics South Africa). (2013). Quarterly Labour Force Survey: Puarter 1, 2013. Available: http://www.statssa.gov.za/publications/P0211/P02111stQuarter2013.pdf. (Accessed 16 July 2013).

Scheepers, D. (2014). Developing a Statement of Financial Position Model for the South African Household Sector. Unpublished PhD thesis. Pretoria: University of South Africa.

Scott, W.R. (2012). Financial accounting theory, 6th edition. Toronto: Pearson Canada.

Shorrocks, A., Davies, J. \& Lluberas, R. (2012). Credit Suisse Research Institute Global Wealth Report 2012. Zurich: Credit Suisse AG.

Subramanian, S. \& Jayaraj, D. (2006). The distribution of household wealth in India. Helsinki: UNUWIDER.

Tustin, D.H., Lighthelm, A.A., Martins, J.H. \& Van Wyk, H de J. (2005). Marketing research in practice, 2005 edition. Pretoria: UNISA Press.

UN (United Nations, European Commission, Organisation for Economic Co-operation and Development, International Monetary Fund \& World Bank Group). (2009). System of National Accounts 2008. New York: UN. 
Van Aardt, C.J. \& Moshoeu, A. (2009). A Consumer Financial Vulnerability (CFV) index for South Africa. Pretoria: BMR.

Walters, S. \& National Accounts Division. (2011). Quarterly Bulletin, No. 262. December.

Woolard, I., Leibbrandt, M. \& Daniels, R. (2014). Getting ahead or falling behind: Findings from the second wave of the National Income Dynamics Study, Development Southern Africa, 31(1), pp. 1-15. 